M. K. Kellogg's Texas Journal, 1872 



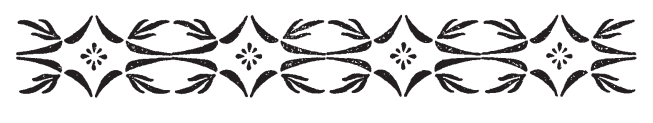

\section{K. Kellogg's}

\section{TEXAS}



1872



Edited with an Introduction by

\section{LLERENA FRIEND}



UNIVERSITY OF TEXAS PRESS AUSTIN 
Copyright (C) 1967 by Llerena B. Friend

First paperback printing 20I4

All rights reserved

Printed in the United States of America

Requests for permission to reproduce material from this work should be sent to:

Permissions

University of Texas Press

P.O. Box 7819

Austin, TX 78713-78I9

http://utpress.utexas.edu/index.php/rp-form

Library of Congress Catalog Number 67-204I7

ISBN 978-0-292-76869-7, paperback

ISBN 978-0-292-76870-3, library e-book

ISBN 978-0-292-7687I-0, individual e-book 
For Daisy and Curtis 
THIS PAGE INTENTIONALLY LEFT BLANK 